\title{
KEANEKARAGAMAN HAYATI DI KAWASAN PANTAI KOTA AMBON DAN KONSEKUENSI UNTUK PENGEMBANGAN PARIWISATA PESISIR
}

\author{
Daniel Anthoni Sihasale \\ Program Doktor Kajian Lingkungan dan Pembangunan, Program Pascasarjana \\ Universitas Brawijaya, Malang, Indonesia
}

\begin{abstract}
Abstrak
Sebagai suatu daerah yang berada di wilayah Indonesia bagian timur, Pulau Ambon memiliki potensi alam yang banyak menawarkan keanekaragaman daya tarik wisata. Dengan kondisi biogeofisik, sosial budaya masyarakat dapat dijadikan sebagai potensi bagi pengembangan pariwisata. Sebagai ibukota propinsi, kota Ambon memiliki pantai dan kelautan dengan keanekaragaman hayati yang khas, sehingga mempunyai peluang untuk dapat dijadikan sebagai objek wisata bahari termasuk potensi wisata bawah laut, dengan hal tersebut maka propinsi Ambon dikenal dengan sebutan "The Spice Island Exotic Marine Paradise". Keberadaan akan potensi wilayah pesisir laut tersebut dewasa ini belum sepenuhnya dikelola dan di kembangkan dengan baik untuk pengembangan pariwisata, hal ini dikarenakan minimnya pemahaman akan bagaimana cara mengelola dan mengembangkan potensi keanekaragaman hayati tersebut dengan baik.
\end{abstract}

Kata Kunci: Keanekaragaman hayati, Kota Ambon, potensi, pengembangan

\section{PENDAHULUAN}

Indonesia terkenal dengan sebutan megabiodiversity, dengan 18 ribuan pulau, sebagai tempat tinggalnya flora dan fauna dari dua tipe yang berbeda asal-usulnya yaitu dari bagian barat (Indo-Malayan) dan bagian timur termasuk kawasan Pasifik dan Australia. Dengan luas daratan hanya 1,3\% dari seluruh daratan bumi, memiliki garis pantai sepanjang 108.000 $\mathrm{km}$, dengan keanekaragaman flora dan fauna yang unik dan menakjubkan. Sekitar $10 \%$ spesies berbunga, $12 \%$ spesies mamalia, $16 \%$ spesies reptil dan amphibia, $17 \%$ spesies burung serta 25\% spesies ikan dunia (BSP-Kemala, 2000). Selain itu memiliki panjang wilayah pesisir mencapai 81,000 kilometer atau sekitar $14 \%$ dari panjang pantai dunia, ekosistem kelautan Indonesia sangat kaya dan bervariasi. Hutan bakau Indonesia sangat luas dan memiliki jenis terumbu karang yang spektakuler di Asia. Perairan pesisir Indonesia menjadi sumber makanan bagi sejumlah besar mamalia laut, reptil, ikan dan burung-burung.

\footnotetext{
* Corresponding Address:

Daniel Anthoni Sihasale

Email : Daniel.sihasale@gmail.com

Address : Program Doktor Kajian Lingkungan, Program Pascasarjana, Universitas Brawijaya Malang, Jl. Veteran, Malang
}

Wilayah pesisir yang dangkal dengan terumbu karangnya dan hutan bakau melindungi wilayah ini dari dampak pasang laut dan tsunami. Sehingga tak heran apabila lebih dari $60 \%$ atau sekitar 140 juta penduduk Indonesia hidup di wilayah pesisir dan laut dan kehidupan mereka bergantung pada sumberdaya hayati laut dan pesisir [13]. Manfaat dan arti penting keanekaragaman hayati pesisir Indonesia telah diterima oleh khalayak luas, tetapi sayangnya, manfaat dan arti penting keanekaragaman hayati wilayah pesisir dan lautan tersebut sangat sedikit dibahas.

Meningkatnya ancaman terhadap ekosistem laut dapat menyebabkan pengrusakan dan penurunan kualitas dan kuantitas diversitas organisme. Ancaman yang terjadi dapat berupa dampak pengembangan industry yang tidak mengedepankan konsep kelestarian lingkungan. Polusi benda padat, cair, dan gas secara tidak langsung dapat menyebabkan perubahan kesetimbangan diekosistem laut.

Adanya potensi keanekaragaman hayati pesisir dan laut Indonesia ini semestinya dapat mendorong berkembangnya industri-industri kepariwisataan yang handal. Sebagai megabiodiversiti, Indonesia mestinya lebih unggul dari Negara-negara lain di dunia dalam hal industri pariwisata, namun menurut Data World Economic Forum menunjukkan, bahwa daya saing pariwisata Indonesia masih lemah dibandingkan 
dengan negara lain. Pada komponen aturan perundangan, Indonesia menempati posisi 108 dengan skor 3.78. Sedangkan untuk komponen infrastruktur dan iklim investasi pariwisata, Indonesia berada pada peringkat 86 dengan skor 3.16. Sementara pada komponen Sumberdaya manusia, budaya dan alam, pariwisata Indonesia berada pada posisi 53 dengan skor 4.17. Secara keseluruhan daya saing pariwisata Indonesia menempati urutan ke 80 dari 130 negara.

Posisi indeks daya saing pariwisata Indonesia jauh tertinggal dibandingkan dengan negara tetangga seperti Singapura, Malaysia dan Thailand. Indeks daya pariwisata Singapura menempati peringkat 16 dengan skor 5.06, disusul kemudian Malaysia pada peringkat 32 dengan skor 5.06, kemudian Thailand pada posisi 42 dengan skor 4.37. Sementara negara-negara ASEAN dengan indeks daya saing pariwisata di bawah Indonesia terdapat Philipina, Vietnam, dan Kamboja masing -masing pada peringkat 81,96, dan 112 [2].

Data Badan Pusat Statistik secara keseluruhan menunjukan bahwa jumlah wisatawan mancanegara (wisman) yang berkunjung ke Indonesia pada Mei 2010 mencapai 600.031 orang, mengalami kenaikan sebesar $15,01 \%$ dibanding bulan yang sama tahun sebelumnya. Demikian pula jika dibanding April 2010, jumlah wisman Mei 2010 mengalami kenaikan sebesar 7,94\%. Secara kumulatif, selama Januari-Mei 2010, jumlah wisman yang berkunjung ke Indonesia mencapai 2.767.122 orang, yang berarti meningkat 14,59\% dibanding jumlah wisman pada periode yang sama tahun 2009 [2].

Propinsi Maluku Sebagai suatu daerah yang berada di wilayah Indonesia Bagian Timur, dengan Ambon sebagai ibukotanya memiliki potensi alam yang banyak menawarkan keanekaragaman daya tarik wisata, baik bersifat alam (bahari, pantai, air terjun/pemandian, hutan termasuk flora dan fauna) maupun budaya yang dapat dikembangkan menjadi tujuan pariwisata yang layak diperhitungkan untuk dikunjungi.

\section{Pariwisata di Ambon}

Berdasarkan data dari kantor Imigrasi Ambon, Polsek dan pusat informasi Disbudpar Maluku di Bandara Internasional Pattimura, juga hotel dan penginapan di Kota Ambon, hingga Agustus 2010 tercatat ada 8.172 wisatawan mancanegara yang mengunjungi Maluku. Jumlah ini mengalami peningkatan sebanyak 5.136 orang dari jumlah wisatawan yang tercatat pada akhir Mei 2010 yang hanya 3.036 orang. Menurut keterangan Kepala Dinas Kebudayaan dan Pariwisata (Disbudpar) Maluku, jumlah tersebut mengalami peningkatan sebanyak $200 \%$. Sementara wisatawan nusantara yang sebelumnya hanya 6.495 orang meningkat tajam hingga 20.936 orang. Sedangkan data wisatawan dari berbagai kabupaten di Maluku yang datang ke Ambon saat Sail Banda berjumlah 17.133 orang. Naiknya angka kunjungan wisatawan mancanegara hingga mencapai 8.000 itu melebihi jumlah yang ditargetkan oleh Disbudpar Maluku, apalagi terjadi hanya dalam waktu tiga bulan (BPMD Propinsi Maluku).

Sebagi Propinsi yang pernah dilanda konflik horizontal terbesar, pada 19 Januari 1999, turut memunculkan berbagai pengaruh negatif dalam kehidupan sosial ekonomi masyarakat Maluku dan menambah beban pemerintah daerah dalam pelaksanaan pembangunan. Sebagai daerah yang selama ini terkenal dalam bidang pariwisata, ternyata ikut mengalami keterpurukan akibat gejolak sosial yang berkepanjangan tersebut. Hilangnya rasa aman dan nyaman akibat kerusuhan di daerah ini, memaksa daerah ini dihindari sejenak oleh para wisatawan, baik domestik maupun mancanegara. Salah satu obyek yang langsung terkena dampak kerusuhan tersebut adalah obyek wisata pantai.

Kondisi keberadaan obyek-obyek wisata pesisir tersebut selama konflik sosial di Maluku sangat memprihatinkan banyak yang terabaikan bahkan tidak terurus, sehingga banyak yang mengalami kerusakan. Potensi akan keanekaragaman hayati di kawasan pesisir yang tadinya merupakan andalan dalam menunjang pengembangan obyek wisata pesisir tidak lagi menjadi sesuatu yang memiliki nilai eksotik. Sementara dulu (sebelum konflik sosial) obyekobyek wisata pesisir tersebut adalah merupakan obyek-obyek wisata yang menarik bagi wisatawan mancanegara dan wisatawan nusantara.

Setelah berakhirnya konflik sosial, pemerintah daerah kembali berupaya membangun dan merenovasi sarana dan prasarana obyek-obyek wisata pesisir tersebut. Usaha mengembalikan citra Kota Ambon sebagai kota wisata bahari terus digalakan kembali demi menarik wisatawan mancanegara dan wisatawan nusantara.

Berdasarkan angka-angka yang di peroleh di atas menunjukan bahwa pembangunan pariwisata di Kota Ambon dari tahun ke tahun 
mengalami perkembangan yang pesat, namun apabila disimak dari sisi perencanaan, pelaksanaan pembangunan dan pengembangannya masih terkesan jauh dari apa yang diharapakan. Pembangunan pariwisata belum secara menyeluruh menyentuh kepada kebutuhan masyarakat akan pariwisata. Potensi keanekaragaman hayati kawasan pesisir, sebagai bagian penting dari suatu proses pembangunan obyek wisata pantai belum seluruhnya diolah dan dikembangkan secara baik. Untuk itu makalah ini bermaksud untuk mendiskripsikan keanekaragaman hayati di kawasan pantai Kota Ambon dan konsekwensinya untuk pengembangan pariwista pesisir.

\section{Keanekaragaman Hayati Pulau Ambon}

Daratan pesisir Kota Ambon sendiri, berada pada posisi $128^{\circ} 00^{\prime} 42^{\prime \prime}$ BT-128 $16^{\prime} 04^{\prime \prime}$ BT dan $3^{\circ} 33^{\prime} 47^{\prime \prime}$ LS - $3^{\circ} 43^{\prime} 50^{\prime \prime}$ LS di semenanjung Leihitu dan posisi $128^{\circ} 04^{\prime} 56^{\prime \prime}$ BT - $128^{\circ} 17^{\prime} 30^{\prime \prime}$ BT dan $3^{\circ} 38^{\prime} 32^{\prime \prime}$ LS - $3^{\circ} 47^{\prime} 06^{\prime \prime}$ LS di semenanjung Leitimur, dengan luas seluruhnya 359,45 km2. (BPS 2002). Memiliki pesisir pantai, dan kelautan dengan keanekaragaman hayati yang khas berpeluang dijadikan sebagai objek wisata, terutama wisata bahari termasuk potensi wisata bawah laut. Dengan memiliki 5 (lima) wilayah ekologis yaitu; (1).Teluk Ambon Dalam (TAD); (2).Teluk Ambon Luar (TAL); (3).Teluk Baguala (TB); (4). Pesisir Selatan Kota Ambon (PSKA); dan (5). Pulau Tujuh (Lucipara). Dari Ke 5 (lima) wilayah ekologis ini, masing-masing memiliki karakteristik potensi keanekaragam hayati yang beragam.

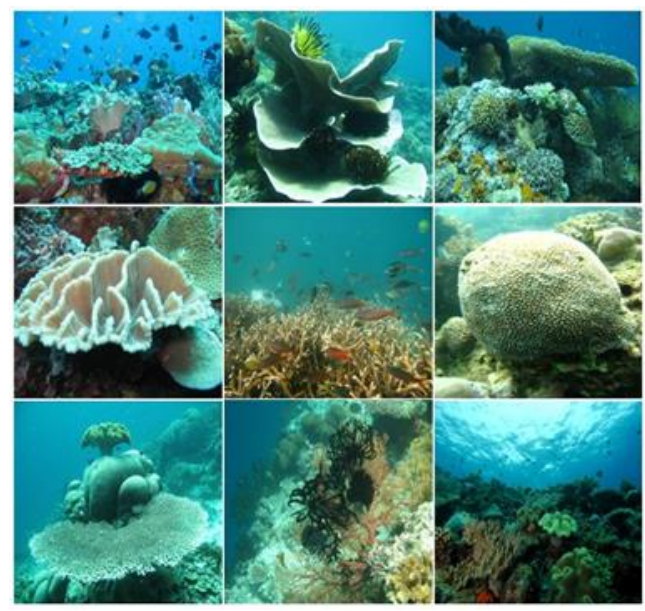

Gambar 1. Terumbu karang

Kota Ambon memiliki latar belakang wilayah laut yang luas dengan total luasnya adalah $658.294,69 \mathrm{Km} 2$, dengan panjang garis pantainya
$8.2872 \mathrm{Km}$. Sedangkan luas wilayah kelola laut (12 mil) adalah sebesar $152.570 \mathrm{Km} 2$, dengan kondisi dominan wilayahnya adalah perairan $(92,4 \%)$, dengan potensi sumberdaya perikanan terdiri dari Ikan Pelagis, Demersal dan Biota laut lainnya yang bernilai ekonomis tinggi. Pada wilayah Maluku juga terdapat 969 jenis kerangkerangan yaitu 665 jenis siput dengan 13 jenis yang bernilai ekonomis dan 274 jenis kerang dengan 21 jenis yang bernilai ekonomis. [28] (Gambar 1, 2, 3, 4).

Terumbu karang merupakan ekosistem yang khas terdapat di daerah tropis seperti di pulau Ambon. Ekosistem ini mempunyai produktivitas organik yang sangat tinggi. Demikian pula dengan keanekaragaman biota yang ada didalamnya. Komponen biota tersebut meliputi hewan karang batu (stony coral), hewan yang tergolong ractinia yang kerangnya terbuat dari bahan kapur. Disamping itu adanya berbagai jenis biota lainnya yang hidupnya mempunyai kaitan erat dengan karang batu ini, seperti misalnya ikan, plankton, alga, lamun, moluska dan yang lainnya. Kesemuanya terjalin dalam hubungan fungsional yang harmonis dalam satu ekosistem terumbu karang.

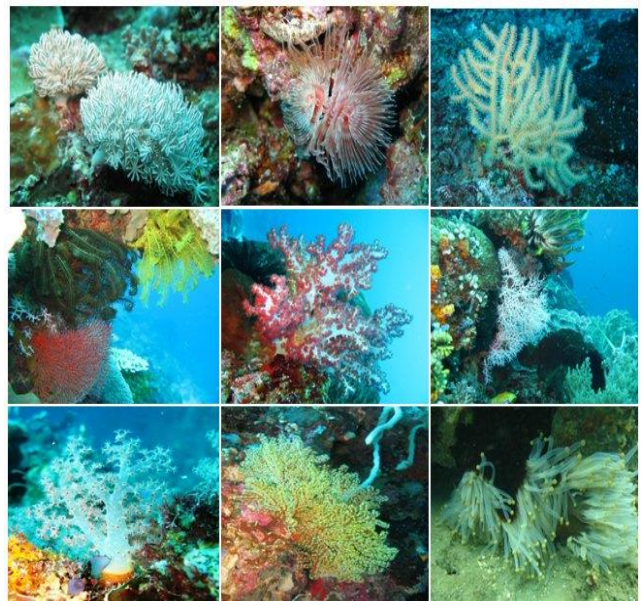

Gambar 2. Marine Cnidaria

Selain keanekaragaman terumbu karang yang di jumpai di pantai-pantai di kota Ambon, juga ditemukan adanya berbagai jenis Spong (sponge). Spoge ini sendiri telah diteliti karena banyak menghasilkan bahan aktif yang potensial untuk dikembangkan menjadi berbagai jenis obat-obatan.

Pada bagian Selatan dari Kota Ambon khususnya di semenanjung Leatimur terdapat beberapa pantai seperti; (a). Pantai Hukurila, pantai (b). Namalatu, (c). Pantai naku, (d). Pintu Kota, (e). Lelisa, (f). Pantai kilang, dan (g). Pantai 
Santai. merupakan sebagaian kecil dari pantaipantai yang berada di Pulau Ambon yang memiliki karakteristik dan potensi yang besar dalam menarik wisatawan untuk melakukan kegiatan berenang, menyelam, memancing dan piknik bersama keluarga. Obyek wisata pantai ini turut memberikan peluang terbukanya lapangan kerja baru bagi masyarakat lokal. (Gambar.5)

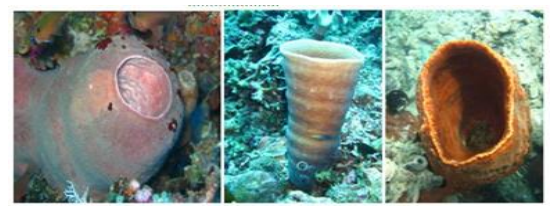

Gambar 3. Sponge

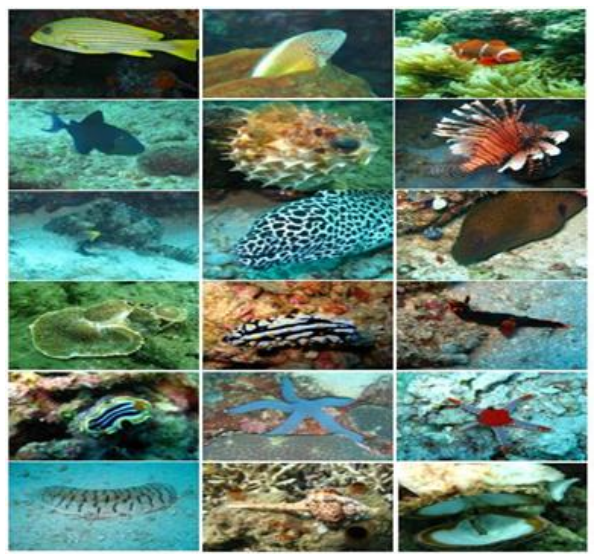

Gambar 4. Marine vertebrates and invertebrates

Potensi keanekaragaman hayati kawasan pantai tersebut secara menyeluruh menyebar di 5 (tiga) kecamatan di Kota Ambon, seperti; 1).Kecamatan Nusaniwe, Kecamatan Sirimau, 3) Kecamatan Teluk Ambon, 4). Kecamatan Teluk Ambon Baguala, dan 5). Kecamatan Leitimur Selatan. Untuk wilayah desa Hutumuri, Rutong, dan Hukurila memiliki kekayaan keanekaragaman hayati kawasan pantai sangat berpotensi untuk dikembangkan sebagai obyek wisata pesisir.

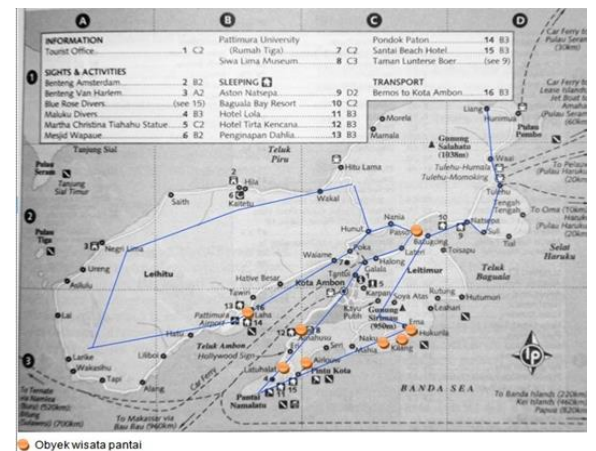

Gambar 5. Peta lokasi obyek wisata pantai di kota Ambon

\section{Pariwisata Berbasis Masyarakat}

Masyarakat Kota Ambon, khususnya masyarakat pesisir yang berada pada lokasi obyek-obyek wisata pantai, belum seluruhnya diikutsertakan dalam pengelolaan dan pembangunan kepariwisataan. Obyek-obyek wisata pantai di Kota Ambon, baik yang dikelola oleh pemerintah maupun yang belum, secara tidak langsung telah memberikan dampak yang luas kepada kondisi sosial ekonomi masyarakat di sekitar lokasi obyek, hal ini terlihat dengan adanya masyarakat yang melakukan aktifitas berjualan atau menjajakan segala bentuk makanan dan menyewakan perlengkapan kebutuhan akan wisata. Usaha masyarakat ini terpaksa mereka lakukan oleh karena adanya tuntutan pemenuhan kebutuhan ekonomi keluarga. Disamping itu usaha tersebut juga terpaksa mereka lakukan karena mereka merasakan bahwa areal pantai yang memiliki potensi untuk pengembangan wisata tersebut adalah merupakan hak ulayat (lahan) milik mereka.

Berdasarkan pengamatan di lapangan ternyata banyak terjadi permasalahan dan keluhan baik dari wisatawan, investor maupun pemerintah sebagai fasilitator. Indeks permasalahan menunjukkan bahwa pengelolaan pantai-pantai di Kota Ambon yang dilakukan masyarakat masih sangat lemah dan perlu pembenahan. Salah satu contoh kasus yaitu obyek wisata Pintu Kota, keberadaan potensi alam pantainya cukup menarik sehingga banyak wisatawan yang datang kesana. Obyek wisata ini pengelolaannya dilakukan oleh masyarakat setempat, secara swadaya oleh unit-unit dari sektor di Jemaat GPM (Gereja Protestan Maluku) Bethesda Air Louw. Pembangunan akan sheltershelter buat pengunjung dilakukan sendiri tanpa adanya bantuan dari pemerintah daerah. Pengelolaan seperti ini tanpa pengelolaan yang lebih baik, dikhawatirkan ada sebagian masyarakat yang memanfaatkan potensi ini sebagai lahan untuk mencari keuntungan pribadi. Misalnya adanya kemungkinan pungutan liar (pungli) menyangkut distribusi masuk, distribusi parkiran kenderaan, distribusi pengunaan fasilitas tempat duduk serta bentuk pungutan liar lainnya.

Pengelolaan pariwisata khususnya obyek wisata pantai di daerah ini masih jauh tertinggal dengan daerah lain di Indonesia. Sektor pariwisata belum mampu memberikan dampak yang signifikan terhadap denyut nadi perekonomian masyarakat disekitar lokasi obyek 
dan hal ini berakibat masih adanya masyarakat yang miskin. Berdasarkan data Badan Pusat Statistik (BPS), keluarga miskin di Ambon saat ini berjumlah 15.100 kepala keluarga (kk). Hal ini disebabkan karena terbatasnya lapangan pekerjaan, kurangnya kemauan untuk berusaha, migrasi dan urbanisasi, serta penyandang masalah kesejahteraan sosial.

Dengan demikian alternatif pemecahan masalahnya adalah perlu adanya pembangunan pariwisata berbasis masyarakat. Pembangunan pariwisata berbasis masyarakat itu adalah merupakan konsep pariwisata alternatif sebagai antisipasi terhadap pariwisata konvensional (Mass Tourism). Pariwisata alternatif mempunyai pengertian ganda, disatu sisi dianggap sebagai salah satu bentuk kepariwisataan yang ditimbulkan sebagai reaksi terhadap dampakdampak negatif dari pengembangan dan perkembangan pariwisata konvensional (Kodyat.1997). Pariwisata kerakyatan itu sendiri pelaku utamanya adalah rakyat, dengan modal, kesederhanaan, dan keunikan kehidupan keseharian serta adat budaya, dimana rakyat akan mendapat nilai tambah (value abded) dalam kehidupan ekonominya [14].

Pariwisata haruslah menekankan kepada 3 (tiga) hal, yakini: 1). Terpeliharanya mutu dan kelanjutan sumberdaya alam dan budaya/keseimbangan, 2). Meningkatkan kesejahteraan masyarakat lokal,3). Serta terwujudnya kepuasan wisatawan. Natori(2001). Sedangkan dalam pengoperasian pengelolaan manajemen komunitas, mengacu kepada tiga alasan mendasar, yaitu: 1). Local Variety, maksudnya variasi kehidupan masyarakat lokal atau kehidupan yang berbeda menuntut system pengelolaan yang berbeda, tidak dapat diberikan perlakuan sama dan masyarakat lokal yang paling akrab dengan situasinya, 2). Local Resource, artinya sumberdaya secara tradisional dikuasai dan dikelola oleh masyarakat setempat, 3). Local Accountabillity, (tanggung jawab lokal), yaitu pengelolaan yang dilakukan oleh masyarakat setempat biasanya lebih bertanggung jawab karena kegiatan yang dilakukan secara langsung akan mempengaruhi hidup mereka. (Korten. 1986).

Tolak ukur pembangunan pariwisata berbasis kerakyatan adalah terciptanya hubungan yang harmonis antara masyarakat lokal, sumberdaya alam/budaya, dan wisatawan. Hal ini dapat dilihat dari: (1).Adanya peningkatan antusiasme pembangunan masyarakat melalui pembentukan suatu wadah organisasi untuk menunjang segala aspirasi masyarakat, (2).Adanya keberlanjutan lingkungan fisik yang ada di masyarakat, caranya melalui konservasi, (3).Adanya keberlanjutan ekonomi melalui pemerataan dan keadilan dalam menikmati hasilhasil pembangunan, (4). Menjaga kepuasan wisatawan melalui pelayanan yang baik [26].

\section{Prespektif Sumberdaya Berkelanjutan}

Pengembangan pariwisata di Kota Ambon harus dapat memanfaatkan potensi perairan laut dan teluk yang ada. Kawasan Pariwisata yang direncanakan haruslah mengarah kepada pengembangan jenis wisata bahari, yang memanfaatkan potensi pantai di Kota Ambon. Kawasan yang diarahkan pengembangannya sekarang ini adalah pada diwilayah Kecamatan Nusaniwe (Desa Latuhalat, Desa Amahusu), Kecamatan Sirimau (Desa Hukurila, Soya), Kecamatan Teluk Ambon Baguala (Desa Passo, Rumah Tiga, Lateri, Negeri Lama, dan Laha). Kawasan-kawasan ini diharapkan menjadi kawasan wisata terpadu dengan dukungan sarana dan prasarana seprti hotel, cottage resort, dermaga, dan sarana lain untuk pengembangan kegiatan Pariwisata.

Pengembangan kegiatan pariwisata pada ke tiga kecamatan ini perlu diarahkan kepada bagaimana mengoptimalkan pemberdayaan potensi pembangunan wilayah pesisir lautan, yaitu dengan melihat kepada: (1).sumberdaya dapat pulih, (2). sumberdaya tak dapat pulih, dan (3).jasa-jasa lingkungan.

Sumberdaya dapat pulih tersebut antara lain seperti hutan mangrove, terumbu karang, padang lamun dan rumput laut, sumberdaya perikanan laut, serta bahan-bahan radioaktif. Sumberdaya tak dapat pulih meliputi seluruh mineral dan geologi, sedangkan yang dimaksud dengan jasa-jasa lingkungan meliputi fungsi kawasan pesisir dan lautan sebagai tempat rekreasi dan pariwisata, media transportasi dan komunikasi, sumber energi, sarana pendidikan dan penelitian, pertahanan dan keamanan, penampung limbah, pengatur iklim, kawasan perlindungan, dan sistem penunjang kehidupan serta fungsi ekologis lainnya.

Pembangunan pariwisata di wilayah pesisir Kota Ambon secara ideal perlu diarahkan kepada bagaimana dapat menciptakan saling keterkaitan dan saling menjaga secara harmonis antara unsur-unsur lingkungan fisik, sosial dan ekonomi. Sehinga diharapkan kegiatan ini dapat meningkatkan pendapatan daerah, memperluas lapangan kerja, mendorong pengembangan jenis 
usaha baru, serta diharapkan mampu meningkatkan kesadaran masyarakat tentang konservasi sumberdaya alam.

Pembangunan pariwisata di Kota Ambon haruslah diarahkan kepada bagaimana membangun pariwisata yang berkelanjutan. Pariwisata berkelanjutan disini diartikan sebagai proses pembangunan pariwisata yang berorientasi kepada kelestarian sumberdaya yang dibutuhkan untuk pembangunan pada masa mendatang, pengertian pembangunan pariwisata berkelanjutan ini pula diartikan "Form of tourism that are consistent with natural, social, and community values and which allow both hosts and guests to enjoy positive and worthwhile interaction and shared experiences" [15].

Penekanan pembangunan pariwisata berkelanjutan itu sendiri tidak hanya pada ekologi dan ekonomi, tetapi juga keberlanjutan kebudayaan karena kebudayaan juga merupakan sumberdaya penting dalam pembangunan kepariwisataan [35]. Konsep pembangunan berkelanjutan itu kemudian oleh Burns dan Holden (1997) diadaptasikan untuk bidang pariwisata sebagai sebuah model yang mengintegrasikan lingkungan fisik (place), lingkungan budaya (host community), dan wisatawan (visitors) [3].

Pada sisi lain masyarakat diarahkan untuk sepatutnya memiliki kepedulian sadar wisata dan menciptakan sapta pesona (keamanan, ketertiban, kebersihan, kesejukan, keindahan, keramahtamahan dan kenangan) [11] dalam upaya menciptakan kepariwisataan yang berkelanjutan (sustainable tourism).

Pembangunan pariwisata hendaknya dilihat sebagai segala sesuatu yang berkaitan dengan fenomena dan relasi yang timbul akibat interaksi antara wisatawan, pengusaha, pemerintah, dan masyarakat dalam proses penciptaan daya tarik dan upaya menjamu wisatawan yang datang [25].

Untuk itu diperlukan strategi yang tepat di berbagai tingkatan, meliputi kebijakan, perencanaan, penganggaran, dan operasionalisasi untuk dapat mengembangkan dan mengelola secara baik potensi kepariwisataan. Untuk mencapai kearah tersebut, maka pariwisata harus mampu diarahkan kepada perbaikan manajemen dan daya tarik wisata dengan memanfaatkan tempat, potensi wisata, objek wisata dengan cara mengatur, membina dan memelihara objek serta wisatawan dengan organisasi pengelola yang ada melalui perencanaan yang matang sesuai tujuan dan sasaran [16].

\section{Diskusi}

Potensi wisata Pesisir di Kota Ambon menyangkut keanekaragaman hayati kawasan pesisir, cukup memberikan nilai dan yang spektakuler, sehingga tak heran bila banyak wisatawan mancanegara maupun wisatawan nusantara mau beramai-ramai datang ke kota ini. Namun potensi yang di miliki tersebut, belum sepenuhnya menjadi keunggulan kompetitif (Competitive Advantage) bagi pemerintah daerah, dan belum dapat memberikan kontribusi besar pada industri pariwisata dan perekonomian daerah. Oleh karena itu agar pariwisata pesisir benar-benar menjadi salah satu penopang perekonomian daerah secara berkelanjutan (An Economicall Sustainable Area/Ecosystem), maka pariwisata pesisir yang ada di Kota Ambon dengan segala bentuk keanekaragaman hayatinya harus di bangun dengan strategi yang terencana dan bervisi jangka panjang.

Pengalaman membuktikan bahwa pengelolaan atau pemanfaatan kawasan pesisir secara sektoral tidaklah efektif ([12]; [3]; [7]; Kay and Alder 1999). Pembangunan harus mengarah kepada pengelolaan wilayah pesisir secara terpadu dinyatakan sebagai proses pemanfaatan sumberdaya pesisir dan lautan serta ruang dengan mengindahkan aspek konservasi dan keberlanjutannya. ([7]; Kay and Alder 1999).

Dalam hal ini pembangunan berkelanjutan merupakan suatu paradigma pemanfaatan sumberdaya alam yang dapat dijadikan konsep dasar pemanfaatan sumberdaya wilayah pesisir di Kota Ambon. Pembangunan berkelanjutan itu sendiri, didefinisikan sebagai [6] "Pembangunan yang dapat memenuhi kebutuhan generasi sekarang tanpa mengorbankan generasi yang akan datang untuk dapat memenuhi kebutuhannya."Pada tingkat yang minimum, pembangunan berkelanjutan tidak boleh membahayakan sistem alam yang mendukung semua kehidupan di muka bumi. Konsep pembangunan berkelanjutan banyak didasari oleh adanya suatu fakta bahwa penggunaan keanekaragaman hayati pada faktanya cenderung mengarah kepada perilaku eksploitasi.

Perlunya dibangun kesadaran masyarakat akan pentingnya keanekaragaman hayati sebagi sumber daya alam, fungsinya dalam prosesproses ekologis dan peranannya dalam hal sosial dan budaya mendorong terciptanya strategi konservasi. Terutama, untuk menjamin persediaan sumber daya hayati dalam konsep pembangunan berkelanjutan [20]. Pengelolaan wilayah pesisir harus secara terpadu PWPT 
(Integrated Coastal zone Management - ICM) adalah pendekatan yang layak untuk mengelola masalah yang ada di wilayah pesisir [9].

\section{DAFTAR PUSTAKA}

[1] Anker HT, Nellemann V, Sverdrup-Jensen S (2004). Coastal zone management in Denmark: ways and means for further integration. Ocean and Coastal Management 47: 495-513.

[2] Badan Pusat Statistik, (2010). Berita Resmi Statistik. Perkembangan Pariwisata Dan Trasportasi Nasional, Mei 2010. No. 41/07/Th. XIII, 1 Juli 2010.

[3] Burns, P. and Holden, A. (1997). Tourism : A New Perspective, Prestice Hall International (UK) Limited, Hemel Hempstead.

[4] Bawa, I Wayan. (1999). Orasi IImiah Wisuda Akademi Pariwisata Mataram. Mataram : AKPAR.

[5] Badan Penanaman Modal Daerah Propinsi Maluku (2007). Gambaran Umum Maluku. 2007, dalam http://www.bkpmdmaluku.com, diakses 19 Januari 2011.

[6] Costanza, R. (Ed.) (1991) Ecological Economics: The Science and Management of Sustainability, Columbia University Press, New York.

[7] Cicin-Sain and R.W. Knecht.(1998). Integrated Coastal and Marine Management. Island Pres. Washington DC.

[8] Chopra R, Verma VK, Sharma PK (2001). Mapping, monitoring and conservation of Harike wetland ecosystem, Punjab, India, through remote sensing. Int. J. Remote Sensing 1: 89-98.

[9] Delaware (1999) University of Delaware, NOAA's National Ocean Service, Intergovernmental Oceanographic Commission, The World Bank, pp. 50.

[10] Dellepiane S, De Laurentiis R, Giordano F (2004). Coastline extraction from SAR images and a method for the evaluation of coastline precision. Pattern Recognition Letter 25: 1461-1470.

[11] Damardjati, R.S. (1987). Istilah- Istilah Dunia Pariwisata. Jakarta : Pradnya Paramita.

[12] Dahuri, R. (1999). Pengelolaan Wilayah Pesisir dalam Kontek Pengembangan Kota Pantai dan Kawasan Pantai Secara Berkelanjutan. Makalah di sampaikan dalam Seminar Nasional Kemaritiman, Jakarta.

[13] Dahuri, R. (2000). Pendayagunaan Sumberdaya Kelautan untuk Kesejahteraan Rakyat. LISPI dan DKP. Jakarta.
[14] Dhyana, Tri Arya. (2004). Pemulihan Ekonomi Bali Melalui Penerapan Pariwisata Kerakyatan Sebagai Perwujudan Ekonomi Kerakyatan. Analisis Pariwisata No.1 Vol.6, Hal 7-10.

[15] Eadington and Smith. (1992). The Emergence of Alternative Form of Tourism. Dalam Valene Smith and WR. Eadington (ed). Tourism Altenative : Potencial and Problem in the Tourism Development. Philadelphia.

[16] Fandeli, Chafid. (1995). Dasar-Dasar Manajemen Kepariwisaaan Alam.Yogjakarta: Liberty Offset.

[17] Frank. L. Cooley (1987) Mimbar dan Tahta. Pustaka Sinar Hrapan. Jakarta.

[18] GESAMP and IMO/FAO/UNESCOIOC/WMO/WHO/IAEA/UN/UNEP (1996).

The Contribution of Science to Integrated Coastal Management, FOOD AND AGRICULTURE ORGANIZATION OF THE UNITED NATIONS, Rome.

[19] Gerakis A, Kalburtji K (1998). Agricultural activities affecting the functions and values of Ramsar wetland sites of Greece. Agric. Ecosys. Environ. 70: 119-128.

[20] Hakim. L. (2004). Dasar-Dasar Ekowisata. Malang: Bayu Media Publishing.

[21] I Gede Pitana, "Overview Pembangunan Pariwisata di Indonesia: Past, Present, and Future", disampaikan pada serial diskusi RPJMN 2010 - 2014 bidang Pariwisata, Bappenas 4 Juni 2008.

[22] Jensen JR, Rutchey K, Koch MS, Narumalani $S$ (1995). Inland wetland change detection in the Everglades water conservation area using a time series of normalized remotely sensed data. Photogrammetric Engineering and Remote Sensing 61: 199-209.

[23] Ketut Wikantika.(2008). Melestarikan Keanekaragaman Hayati Indonesia Dengan Teknologi Penginderaan Jauh. 2008, dalam http://www.bps.kemala.com, diakses 19 Januari 2011.

[24] Korten David C. (1986). Community Management Asian Experience And Perspective. Connecticut. Kumarian Press.

[25] Mclntosh, Robert W. and Charles R. Goeldner. (1986). Tourism, Principles, Practices, Philosophies. New York: John Wiley \& Sons, Inc.

[26] Natori, Masahito. (2001). A Gudebook For Tourism Based Community Development. Aptec Osaka-Japan. 
[27] Ringrose S, Matheson W, Boyle T (1988). Differentiation of ecological zones in the Okavango Delta, Bostwana, by classification and contextual analyses of Landsat MSS data. Photogrammetric Engineering and Remote Sensing 54: 601-608.

[28] Rifai., Mien. A, (1990); Biodiversity Flora Hutan Tropis di Dalam Wallacea Area. Kumpulan Makalah Lokakarya Nasional Pengembangan Riset Pelestarian dan Pemanfaatan Sumberdaya Alam.

[29] Suwantoro, Gamal. (2004). Dasar-Dasar Pariwisata. Yogyakarta : Penerbit Andi.

[30] Soegiarto dkk. (1978); Rumput Laut (Algae): Manfaat, Potensi dan Usaha Budidayanya. Lembaga Osceanologi Nasiona LIPI.

[31] Sherman, P. and J. Dixon, (1991), The economics of nature tourism : Determining if it pays. In Nature Tourism : Managing for the Environment, T. Whelan (ed.), Island Press, Washington, DC.

[32] Sekolah Pasca Sarjana IPB, Strategi Pengelolaan Sumberdaya Pesisir Dan Lautan, Makalah Kelompok 7 Semenster Ganjil 2004 Falsafah Sains (PPS-702) Program Pasca Sarjana S3, November 2004, hal. 3
[33] Titah Siwalima.(2010). 8.172 Wisatawan Asing Kunjungi Maluku dalam http://titahsiwalima.com/?p=1615.

[34] Vitousel PM, Mooney HA (1997). Estimates of coastal populations. Sci. 278: 211-1212.

[35] Wall, G. (1993). Towards a Tourism Typology. Dalam JG. Nelson, R. Buttler and G. Wall (ed) Tourism and Sustainable Development: Monitoring, Planning, managing. Waterloo Dept. of Gegraphy Univ. Waterloo. 23.

[36] Wang Z, Zhang B, Zhang S, Li X, Liu D, Song K, Li J, Li F, Duan H (2006). Changes of land use and of ecosystem service values in Sanjiang Plain, Northeast China. Environmental Monitoring and Assessment 112: 69-91.

[37] W. Pattinama dan M. Pattipelohy. Upacara Sasi Ikan Lompa di Negeri Haruku. Kementrian Kebudayaan dan Pariwisata Balai Kajian Sejarah dan Nilai Tradisional. Ambon 2003.

[38] Yoeti, Oka. 1997. Ekowisata : Pariwisata Berwawasan Lingkungan Hidup. Jakarta: P.Pertja. 